Kovács Petra'

\title{
Nők a Brit Királyi Légierő kötelékében (1938-1944)
}

Women Serving in the Royal Air Force (1938-1944)

\section{Absztrakt}

A második világháború során nem csak férfiak szolgáltak a Brit Királyi Légierő (Royal Air Force - a továbbiakban: RAF) kötelékében. Sir Kingsley Wood, légügyi miniszter létrehozta 1938-ban a Polgári Légi Örséget (Civil Air Guard) a Brit Királyi Légierő feladatainak segitésére. 1939 júliusára a licencet szerzettek száma három- és négyezer közé tehetö, valamint további tízezer pilóta állt kiképzés alatt (ebböl 900 nő).

Kulcsszavak: második világháború, $R A F$, lengyel, pilóták, nök

\section{Abstract}

During World War II not only men served in the Royal Air Force. Sir Kingsley Wood, the Air Minister formed the Civil Air Guard for supporting the Royal Air Force. Until July 1939 between three and four thousand people got their licence and there were further ten thousand who were under training. (Nine hundred of them were women.)

Keywords: World War II, RAF, Polish, pilots, women 


\section{A Brit Királyi Légierő (Royal Air Force - RAF) felépítése}

A Brit Királyi Légierőt elsősorban önálló haderőnemként kezelték, mivel Anglia egyetlen jelentősebb hadereje a haditengerészeten kívül ez volt. 1936-ban a következő szervezeteket hozták létre:

- Bombázó-parancsnokság (Bomber Command) - a légierő magja;

- Vadászrepülő-parancsnokság (Fighter Command) - amelynek feladata a légvédelem volt, valamint ők működtek együtt a szárazföldi erőkkel;

- Parti Parancsnokság (Coastal Command) - akik támogatták a haditengerészetet, valamint

- Training Command - a kiképzési feladatok ellátására.

1937-ben az RAF az Admiralitásnak átadta a haditengerészeti repülői egy részét. Létrehozták az Ellátó-parancsnokságot (Maintenance Command) a beszerzési és ellátási feladatok végrehajtására. A polgári repülés és az önkéntesek a Tartalékok Parancsnoksága alá tartoztak (Reserve Command), továbbá a Léggömbparancsnokság (Balloon Command) szintén. Az RAF alapegysége a repülőszázad (squadron) volt. Ez a háború előtt 12 egymotoros gépből vagy 10 kétmotoros gépből állt. 2-3 repülőszázad alkotott egy repülőegységet (wing), több wing pedig egy csoporttá (group) szerveződött. ${ }^{2}$

\section{Légi Szállítási Tartalékos Légierő (Air Transportation Auxiliary - ATA)}

Sir Kingsley Wood, légügyi miniszter 1938. július 23-án létrehozta a Polgári Légi Őrséget (Civil Air Guard) a Brit Királyi Légierő feladatainak segítésére. Csatlakozhatott hozzá minden 18 és 50 év közötti személy, aki valamely repülőklub tagja volt, nemre való tekintet nélkül. 1939 júliusára a licencet szerzettek száma három- és négyezer közé tehető, valamint további 10 ezer pilóta állt kiképzés alatt (ebből 900 nő). ${ }^{3}$ Gerard d'Erlanger, a British Airways akkori igazgatója előre látta, hogy lesznek olyan pilóták, akik nem lesznek alkalmasak az RAF kötelékében szolgálni a koruknál fogva, viszont egyéb szállítási, támogatási feladatokat elláthatnak. A kezdeményezését azonnal elfogadták, így jött létre a Légi Szállítási Tartalékos Légierő (Air Transportation Auxiliary - a továbbiakban: ATA). ${ }^{4}$

1939-ben az ATA-hoz kerülés feltételei a következőek voltak: minimum „A"-típusú magánpilóta szakszolgálati engedély, néhány száz repült óra, férfiak esetében 28-50 év, nőknél 22 év volt az alsó korhatár, mivel a férfiak 28 év alatt hadkötelesek voltak. ${ }^{5}$ A női pilóták a többi szervezettel ellentétben egyenrangúak voltak a férfiakkal, egyazon

Groehler, Olaf: A légi háborúk története. Második, átdolgozott kiadás, Zrínyi Katonai Könyv- és Lapkiadó, Budapest, 1983, 108-119.

Curtis, Lettice: The Forgotten Pilots: A Story of the Air Transport Auxiliary, 1939-45., Henley-on-Thames, Foulis, 1971, 10. Schrader, Helena Page: Sisters in Arms: The Women Who Flew in World War II, Pen \& Sword Aviation, South Yorkshire, 2015, 5 .

Schrader (2015): i. m. 23 
szervezetnél szolgáltak, ugyanazt az egyenruhát viselték, ugyanazt a képesítést és feladatokat kapták. A rendfokozatokat az döntötte el, hogy milyen kiképzést végeztek el a pilóták. Az újonnan bekerülő pilótajelölteket kadétoknak hívták. Az egymotoros repülőgép-vezetői engedély megszerzése után megkapják a Third Officer rendfokozatot, ami a Brit Királyi Légierőben a Pilot Officernek, magyarul pedig repülőtisztnek felelt meg. A First Officer, azaz repülő hadnagyi kinevezés után azok léphettek feljebb a ranglétrán, akik adminisztratív feladatokat vagy csapatot irányítottak. ${ }^{6}$ A fizetésbeli különbségek eleinte elég szélsőségesek voltak a férfi és a női pilóták között, ám ezt 1943 júniusára teljesen megszüntették. ${ }^{7}$

Az ATA szállítópilótái speciális kiképzést kaptak, amelynek a fő irányvonalai a következők voltak: a repülőgépek típusa és osztályozása szerinti képesítés biztosítása, tapasztalatszerzés és navigációs képzés, a felkészülés és a szállítói szolgálat beosztása - figyelembe véve az egyéni adottságokat -, viszont nem oktatták a müszeres repülést, mürepülö-kiképzést, kötelékrepülést és a rádióhasználatot. ${ }^{8}$ Ennek oka igen egyszerü volt: az ATA-pilóták feladata az volt, hogy a gépeket épségben átrepüljék az adott területre, valamint legtöbbször a gyárból repülték át azokat a karbantartóegységekhez és még nem voltak rádióval felszerelve. ${ }^{9}$ A repülőgépeket hat osztályba sorolták be típusuk szerint. Néhány példa a második világháború során bevetett, ismertebb repülőgépekről: a Hurricane, Spitfire, Typhoon a II. osztályba; a Halifax, a Lancaster és a hasonló nehézbombázók az. V. osztályba tartoztak. ${ }^{10}$

A pilóták az I. típusvizsga letétele után az adott kategóriába tartozó repülőgépekkel végeztek szállításokat mindaddig, míg meg nem szerezték a következő osztályra a képesítést. Csak akkor válhattak hivatásos szállítópilótává, ha megszerezték azt a III. osztályú gépekre is. ${ }^{11}$

June Farquhar az alábbiakat írta a kiképzésről: „Milyen nagyszerű tréning és mily magabiztossá tett mindnyájunkat. Még mindig csodálom azt a tényt, hogy egy teljesen ismeretlen repülőgépbe mászhattunk bele, végiglapoztuk a Pilóták Kezelési Kézikönyvét, időt töltöttünk a repülőgép megismerésével és [...] aztán bele a nagy kékségbe!"12

Az ATA-pilóták munkája igen kemény volt. Hét napból hetet repültek, soha nem küldték őket pihenni (szemben az RAF pilótáival). ${ }^{13}$ A repüléseik sem voltak teljesen veszélytelenek. Mint azt korábban említettem, a gépek rádiókapcsolat nélkül repültek, ezért mindig megvolt a veszélye, hogy esetlegesen ellenséges gépként érzékelik őket harci területek fölé történő berepülésük során.

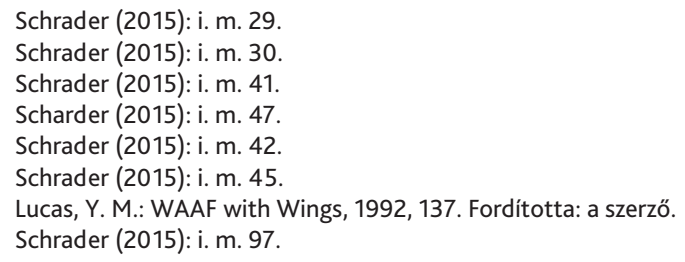




\section{Női Tartalékos Légierő (Women's Auxiliary Air Force - WAAF)}

A Női Tartalékos Légierőt 1939. június 28-án alapították. ${ }^{14}$ Az itt szolgáló nők feladatainak listája széles körü volt, a fözéstől a meteorológiai adatok közzétételéig, az adminisztratív feladatoktól a repülőgép-szerelésig/-karbantartásig tartott, ám nem repültek gépeket. ${ }^{15}$ Kiemelt fontosságú feladatuk volt a radarok figyelése, az angliai csata ideje alatt pedig a műveleti szobákban való szolgálat.

A WAAF tagjai közül jó néhányan speciális kiképzést kaptak a Churchill titkos hadseregeként emlegetett Különleges Hadműveleteket Végrehajtó Egység (Special Operations Executive - SOE) toborzásának köszönhetően.

\section{A Lengyel Női Tartalékos Légierő (Pomocnicza Lotnicza Służ- ba Kobiet - PLSK) az RAF állományában}

Lengyelország 1939-es megszállását követöen a lengyel kormány áttette székhelyét Romániába, majd Párizsba. 1939. szeptember 30-án Władysław Raczkiewicz emigráns elnök megbízta Władysław Sikorski tábornokot, hogy hozzon létre egy új lengyel kormányt. A kormány 1940 nyaráig Párizsban székelt, majd Franciaország összeomlása után Winston Churchill miniszterelnök meghívására áttette székhelyét Londonba. ${ }^{16}$ Amikor 1941-ben a szovjet-német háborúval Szovjetunió nemzetközi helyzete megváltozott, Sztálin elkezdett segítséget kérni más, Németországgal ellenséges országoktól. 1941. július 5-én Anthony Eden, a brit külügyminisztérium diplomatája, valamint Sikorski tábornok tárgyalásokat kezdett a szovjet nagykövettel, Ivan Majskijjal Londonban, ezzel megkezdve a Lengyelország és a Szovjetunió közötti diplomáciai kapcsolatok helyreállítását. ${ }^{17}$

Sztálin beleegyezett abba, hogy az összes korábbi paktumot semmisnek nyilvánítsa a náci Németországgal, megsemmisítve az 1939. szeptemberi lengyelországi szovjet-német partíciót. A lengyel kormány és Sztálin között létrejött megállapodás értelmében, 1941. augusztus 12-én a szovjetek lengyel állampolgároknak adtak „amnesztiát”, közülük kerültek ki a 40 ezer fős lengyel hadsereg tagjai (amely később Władysław Anders tábornok után Anders Hadseregként ${ }^{18}$ vált ismertté). ${ }^{19}$ Władysław Anders tábornok kezdeményezésére 1941 szeptemberében létrehozták a lengyel Női Tartalékos Légierőt, amelybe a tagok toborzása már augusztusban megkezdődött. ${ }^{20}$

14 Narracott, A. H.: How the RAF Works, F. Muller Limited, 1941, 108. https://archive.org/details/howtherafworks030792mbp/ page/n115 (Letöltve: 2019. 04. 26.)

15 Women's Auxiliary Air Force (WAAF) 1939-1949, www.rafmuseum.org.uk/research/online-exhibitions/women-ofthe-air-force/womens-auxiliary-air-force-waaf-1939-1949.aspx (Letöltve: 2019. 04. 26.)

6 Szokolay Katalin: Lengyelország története, Balassi Kiadó, Budapest, 1997, 179.

17 Mikolajczyk, Stanislaw: The Pattern of Soviet Domination, Sampson Low, Marston \& Co., 1948, 18.

18 Más néven II. lengyel hadtest részt vett a palesztinai és az észak-afrikai hadműveletekben, 1943-ban ott voltak a szövetséges erők dél-olaszországi partraszállásánál. Az egység legragyogóbb győzelme a Monte Cassinó-i csata volt.; Władysław Anders, https://mult-kor.hu/20070810_wladyslaw_anders (Letöltve: 2019. 05. 26.)

19 Piesakowski, Tomasz: The Fate of Poles in the USSR 1939-1989, Gryf Publications, London, 1990, 77.

20 Pomocnicza Lotnicza Służba Kobiet, www.polishairforce.pl/waaf.html (Letöltve: 2019. 04. 26.) 
Stanisław Ujejski tábornok - 1940 márciusa és júliusa között a lengyel légierő helyettes parancsnoka megfigyelőként javasolta Marian Kukieł tábornoknak - aki ekkor a lengyel emigráns kormány honvédelmi miniszterhelyettese volt -, mintegy 1500 önkéntes felvételét a lengyel Női Tartalékos Légierőbe. Ennek hatására 1942. december 2-án Kukieł tábornok kiadott egy rendeletet, amiben felszólította az Egyesült Királyságban élő lengyel nőket a PLSK-hoz való csatlakozásra. 1943 áprilisában 36 nőt választottak ki a további önkéntesek oktatóinak. Közülük Helena Paszkiewiczet, aki elhagyta a brit Női Tartalékos Légierőt, hogy csatlakozzon a PLSK-hoz. Öket a lengyel felvételi kurzusra küldték Skóciába, ami május 1-jétől június 10-éig tartott. Június 17-én a WAAF tagjai lettek és elküldték őket a brit tanfolyamra Wilmslow-ba. Faldingworth repülöterén számos lengyel nő dolgozott a lengyel szerelőkkel együtt a Lancastereken a 300. bombázórepülö-században. A lengyel Női Tartalékos Légierő tagjait végül 26 repülötéren helyezték el. Az önkéntesek főként lengyel egységekben dolgoztak, de az angol állomásokon is. A női tisztek nyolc területen dolgoztak: RAF és WAAF adminisztrációja, titkosszolgálat, számvitel, raktározás és anyagellátás, élelmiszer-ellátás, titkosírás és oktatás. Az önkéntesek, valamint a nem megbízott tisztségviselők és a magántisztviselők 45 szakterületen dolgoztak, ellátva például a következő feladatokat: alkalmazottak adminisztrációi, pincérnők, szakácsok, repülésirányító tisztviselők, repülésvezérlő helyiségekben való szolgálat, meteorológiai szolgálatok, rádióadók, valamint távírók üzemeltetése, telefonos szolgálat, ügyintézők, autóvezetők, raktárakban való segítség, beszállítók, mechanikusok és technikusok - az utolsó területekre a lengyel technikai iskolában végzetteket osztották be.

1943 júniusától 1945 júniusáig 1436 lengyel nő - 17 és 43 év közöttiek - csatlakozott a lengyel Női Tartalékos Légierőhöz; 52 közülük tiszt és 110 tiszthelyettes lett. 1945. május 8-án 1137-en szolgáltak a brit Női Tartalékos Légierőben. ${ }^{21}$

A háború után a legtöbb önkéntes nem tért vissza Lengyelországba. Többen azért sem, mert a határok átrendeződése miatt a családjuk a Szovjetunióba került, vagy éppen megházasodtak Nagy-Britanniában. Sokan maradtak a női tartalékos légierőnél az Egyesült Királyságban, amely további kétéves szolgálatot jelentett. Ezalatt tovább képezhették magukat különböző civil munkákra, kereshettek állást vagy ösztöndíjat kaphattak különböző angol egyetemekre, oktatási intézményekbe. ${ }^{22}$ További szervezetek jöttek létre Észak-Amerikában és Nagy-Britanniában: 1972-ben Torontóban Anna Ejbich vezetésével megalapították a PLSK-WAAF Szekciót, 1977-ben Zofia BojkoBiałkowska vezetésével a Nottinghami Szekciót. 2004-ben a XXX. Kongresszuson a lengyel Női Tartalékos Légierőt megszüntették. ${ }^{23}$

\footnotetext{
21 Pomocnicza Lotnicza Służba Kobiet (PLSK-WAAF) https://listakrzystka.pl/pomocnicza-lotnicza-sluzba-kobiet-plsk-waaf/ (Letöltve: 2019. 04. 26.)

22 Uo.

23 Schrader (2015): i. m. 124.
} 


\section{A legkiemelkedőbbek}

Joan Lily Amelia Hughes (1918-1993)

Az első nyolc női pilóta egyike, akik a Légi Szállítási Tartalékos Légierőhöz csatlakoztak. A háború végére az egyik legtapasztaltabb pilóta lett, aki rendelkezett szakszolgálati engedéllyel az összes katonai repült típusra. Csaknem 600 órát repült az ATA kötelékében. ${ }^{24}$

Ruth Helen Kerly (1916-1992)

Azon két nő egyike, akik dicséretben részesültek az ATA-nál végzett szolgálatuk idején. 1944. június 25-én egy Spitfire átrepülése közben műszaki hiba lépett fel, ám ő sikeresen landolt egy mezőn. A gépben minimális kár keletkezett. ${ }^{25}$

Margaret Fairweather (1901-1944)

A nyolc első női ATA-pilóták egyike, valamint az első nő, aki Spitfire-gépeken végzett légi tevékenységet. 1931 óta rendelkezett repülési szakszolgálati engedéllyel és a Skót Repülőklub tagjaként instruktori feladatot látott el. ${ }^{26} 1944$. április 3-án egy repülögép-szerencsétlenségben vesztette életét. ${ }^{27}$

\section{Wanda Szuwalska (1923-)}

1943-ban jelentkezett önkéntesnek a légierő szolgálatába. 1944-ben a Lengyel Női Tartalékos Légierőhöz osztották be. A kéthónapos tanfolyam elvégzése után a 300. bombázórepülö-századnál teljesített szolgálatot Faldingworthben, a légiirányító-toronyban. Feladatai közé tartozott a négymotoros Lancaster bombázó-repülőgépeken szolgálatot teljesítő lengyelek esetében a harci repülésekből visszatérő személyzet tájékoztatása a szélirányról, valamint a futópályák és a parkolóhelyek számának megadása. ${ }^{28} \mathrm{Az}$ irodában pedig a különböző jelentések készítését kapta feladatul. 1944 novemberében áthelyezték London mellé, a Vadászrepülő-parancsnoksághoz, ahol a lengyel vadászpilóták gyakorló- és élesbevetési repüléseinek adminisztrációjával, valamint a pilóták repülési naplójának ellenőrzésével bízták meg. ${ }^{29}$

24 Hughes, Joan Lily Amelia, www.oxforddnb.com/view/10.1093/ref:odnb/9780198614128.001.0001/odnb-9780198614128e-67664;jsessionid=BD991F7FE1F8211314973A01AC2E0ED0 (Letöltve: 2019. 04. 26.)

25 Mistery of the Spitfire heroine, www.thefreelibrary.com/MYSTERY+MYSTERY+OF+THE+OF+THE+SPITFIRE+SPITFIRE+HEROINE+HEROINE.-a0392609899 (Letöltve: 2019. 04. 26.)

26 Ellis, Mary: A Spitfire Girl: One of the World's Greatest Female ATA Ferry Pilots Tells Her Story, Frontline Books, $2017,75$.

27 Margaret Fairweather, https://en.wikipedia.org/wiki/Margaret_Fairweather (Letöltve: 2019. 04. 26.)

28 Interview with Wanda Szuwalska, https://ibccdigitalarchive.lincoln.ac.uk/omeka/collections/document/3498 (Letöltve: 2019. 04. 26.)

29 Wanda Szuwalska, www.polishairforce.pl/szuwalska.html (Letöltve: 2019. 04. 26.) 


\section{Wanda Vrabetz (1924-2016)}

1944. július 13-án került be a Lengyel Női Tartalékos Légierőbe. Ugyanezen a napon kezdte meg kéthónapos kiképzését, hogy a brit WAAF tagja lehessen. A kiképzés után, 1944 szeptemberében a korábbi tanulmányai miatt (utásznak tanult) a Repülőtéri Építési lgazgatóság Tervezőirodájába rendelték a Légierő Parancsnoksághoz. Müszaki rajzokat készített, amelyek a repülőterek és futópályák építésére vonatkozó utasítások mellékletei lettek. Több hónapnyi szolgálat után kérte, hogy részt vehessen egy érettségi-előkészítő tanfolyamon. Az érettségi letétele után, 1946-ban a Dunholme Lodge légi bázisára került, majd 1947-ben Framlinghambe. Itt várta meg a Lengyel Légierő megalakulását. Megkapta az Air Medal kitüntetést. ${ }^{30}$

Jadwiga Piłsudska-Jaraczewska (1920. feburár 28. - 2014. november 16.)

Jadwiga Piłsudksa 1920. február 28-án született Varsóban, Józef Piłsudski kisebbik lányaként. Gyerekkora óta rajongott a repülésért, 1937-ben megszerezte a vitorlázórepülőszakszolgálati engedélyét, majd folytatta pilótaképzését. 1939 szeptemberében el akarta kezdeni repülőmérnöki tanulmányait a varsói egyetemen, de a német invázió közbeszólt. Nagy-Britanniában a Cambridge Egyetemen kezdte meg építészeti tanulmányait, közben jelentkezett a Légi Szállítási Tartalékos Légierőhöz, amelyhez csak 1942-ben csatlakozhatott, félbehagyva tanulmányait. Miután kiképzést kapott kisgépes repülésből, áttérhetett olyan vadászrepülőkre, mint például a Hurricane és a Spitfire. ${ }^{31}$ Nemsokkal ezután kinevezték Second Officernek, ami lehetővé tette a IV. osztályú bombázók átrepülését műveleti területekre. ${ }^{32}$

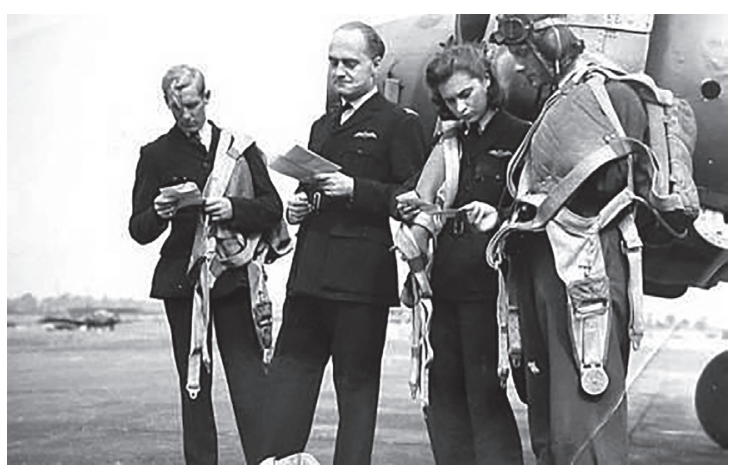

1. ábra: Jadwiga Pitsudska az ATA tisztjeivel

Forrás: Jadwiga Pilsudska-Jaraczewska - obituary, www.telegraph.co.uk/news/obituaries/11245441/Jadwiga-Pilsudska-Jaraczewska-obituary.html (Letöltve: 2019. 04. 26.)

30 Pomocnicza Lotnicza Służba Kobiet, www.polishairforce.pl/vrabetz.html (Letöltve: 2019. 04. 26.)

31 Jadwiga Pilsudska-Jaraczewska - obituary, www.telegraph.co.uk/news/obituaries/11245441/Jadwiga-Pilsudska-Jaraczewska-obituary.html (Letöltve: 2019. 04. 26.)

32 Jadwiga Piłsudska, www.polishairforce.pl/pilsudska.html (Letöltve: 2019. 04. 26.) 
1944-ben otthagyta a légierőt, és megkezdte tanulmányait a liverpooli egyetem Lengyel Építészeti iskolájában, ahol 1946-ban szerzett építészmérnöki diplomát. Soha nem igényelt brit állampolgárságot, úgynevezett Nansen-útlevéllel utazott, amivel mindenhova mehetett, kivéve Lengyelországot. 1990-ben tért haza Varsóba a férjével, Andrzej Jaraczewskivel. ${ }^{33}$

\section{Felhasznált irodalom}

Curtis, Lettice: The forgotten pilots: a story of the Air Transport Auxiliary, 1939-45., Henley-on-Thames, Foulis, 1971.

Ellis, Mary: A Spitfire Girl: One of the World's Greatest Female ATA Ferry Pilots Tells Her Story, Frontline Books, 2017.

Groehler, Olaf: A légiháborúk története. (Második, átdolgozott kiadás), Zrínyi Katonai Könyv- és Lapkiadó, Budapest, 1983.

Lucas, Y.M.: WAAF with Wings, GMS Enterprises, 1992.

Mikolajczyk, Stanislaw: The Pattern of Soviet Domination, Sampson Low, Marston \& Co., 1948.

Narracott, A. H.: How the RAF works, F. Muller Limited, 1941.

Piesakowski, Tomasz: The Fate of Poles in the USSR 1939-1989, Gryf Publications, London, 1990.

Schrader, Helena Page: Sisters in Arms: The women who flew in World War II, Pen \& Sword Aviation, South Yorkshire, 2015.

Szokolay Katalin: Lengyelország története, Balassi Kiadó, Budapest, 1997.

\section{Internetes források}

Hughes, Joan Lily Amelia, www.oxforddnb.com/view/10.1093/ref: odnb/9780198614128. 001.0001/odnb-9780198614128-e-67664;jsessionid=BD991F7FE1F8211314973A01AC2EOEDO (Letöltve: 2019. 04. 26.) DOI: https://doi.org/10.1093/ref:odnb/67664 Interview with Wanda Szuwalska, https://ibccdigitalarchive.lincoln.ac.uk/omeka/collections/document/3498 (Letöltve: 2019. 04. 26.)

Jadwiga Piłsudska, www.polishairforce.pl/pilsudska.html (Letöltve: 2019. 04. 26.) Jadwiga Piłsudska-Jaraczewska - obituary, www.telegraph.co.uk/news/obituaries/

11245441/Jadwiga-Pilsudska-Jaraczewska-obituary.html (Letöltve: 2019. 04. 26.) Mistery of the Spitfire heroine, www.thefreelibrary.com/MYSTERY+MYSTERY+OF+ THE+OF+THE+SPITFIRE+SPITFIRE+HEROINE+HEROINE.-a0392609899 (Letöltve: 2019. 04. 26.)

Pomocnicza Lotnicza Służba Kobiet (PLSK-WAAF) https://listakrzystka.pl/pomocnicza-lotnicza-sluzba-kobiet-plsk-waaf/ (Letöltve: 2019. 04. 26.)

Wanda Szuwalska, www.polishairforce.pl/szuwalska.html (Letöltve: 2019. 04. 26.) www.polishairforce.pl/vrabetz.html (Letöltve: 2019. 04. 26.)

33 Jadwiga Piłsudska, www.polishairforce.pl/pilsudska.html (Letöltve: 2019. 04. 26.) 
Władysław Anders, https://mult-kor.hu/20070810_wladyslaw_anders (Letöltve: 2019. 05. 26.)

Women's Auxiliary Air Force (WAAF) 1939-1949, www.rafmuseum.org.uk/research/online-exhibitions/women-of-the-air-force/womens-auxiliary-air-forcewaaf-1939-1949.aspx (Letöltve: 2019. 04. 26.) 